\title{
Corrigendum: Photon number statistics uncover the fluctuations in non-equilibrium lattice dynamics
}

Martina Esposito, Kelvin Titimbo, Klaus Zimmermann, Francesca Giusti, Francesco Randi, Davide Boschetto, Fulvio Parmigiani, Roberto Floreanini, Fabio Benatti \& Daniele Fausti

Nature Communications 6:10249 doi: 10.1038/ncomms10249 (2015); Published 22 Dec 2015; Updated 1 Feb 2016

The affiliation details for Davide Boschetto are incorrect in this article. The correct affiliation details for this author are given below: Laboratoire d'Optique Appliquée, ENSTA ParisTech, CNRS, Ecole polytechnique, Université Paris-Saclay, 828 boulevard des Maréchaux, 91762 Palaiseau cedex, France.

This work is licensed under a Creative Commons Attribution 4.0 International License. The images or other third party material in this article are included in the article's Creative Commons license, unless indicated otherwise in the credit line; if the material is not included under the Creative Commons license, users will need to obtain permission from the license holder to reproduce the material. To view a copy of this license, visit http://creativecommons.org/licenses/by/4.0/ 